\title{
Review on Biological activity of $\beta$-Lactams, Pyrazoles, Thiazoles and Quinones
}

\author{
N.A.A. El-Kanzi ${ }^{(a, b) *}$ \\ a- Chemistry Department, Faculty of Science, Aswan University, Aswan, Egypt. \\ b-Chemistry Department, Faculty of Science, Al-Jouf University, Sakaka, Al-Jouf, KSA.
}

\begin{abstract}
The present review article is concerned about the biological activity of $\beta$-Lactams, Pyrazoles, Thiazoles and quinones, in this review article emphasis is given on the biological activities of $\beta$-Lactams, Pyrazoles, Thiazoles and quinones derivatives. Some derivatives of $\beta$-Lactams possess various other useful pharmacological effects, for example, inhibitors of human leucoyte elastase, cholestrol acyl transferase, an thrombin.
\end{abstract}

Key Words: Biological activity, $\beta$-Lactams, Pyrazoles, Thiazoles, quinines.

\section{Biological activity of $\beta$-Lactams:}

\section{Introduction:}

Scince the discovery of pencillin, $\beta$-lactams (including pencillin, cephalosporins, monobactams, and carbapenems) have become a major class of antibacterial agents. Because of their widespread use. Bacterial resistancehas developed into a major health problem worldwide over the past few decades. Some derivatives of $\beta$-Lactams possess various other useful pharmacological effects, for example, inhibitors of human leucoyte elastase, cholestrol acyl transferase, an thrombin. Azetidin-2-one derivatives are versatile intermediates in the construction of complex heterocycles, non-proteogenic amino acid derivatives, peptides and turn mimetics. They can be used in synthetization of different natural compounds, such as apioporamide or taxol derivatives.

\section{Peter Cosomo et al., 2008. ${ }^{1}$}

The explosive interest in $\beta$-Lactams and related derivatives stems from the fact that some monocyclic $\beta$-Lactams exhibit antibacterial activities. Some examples comprise the naturally occurring mono-bactams (1) and nocardicins (2) Durckheimer et al., $\mathbf{1 9 8 5}^{2}$. Contrary to penicillins, cephalosporins, or nocardicins, monobactams were not produced by fungi or actinomycetes, but from bacteria, for example, Bacillus, pseudomonas, Cimarusti et al., $\mathbf{1 9 8 3}^{3}$. Nocardicins proved the relationship with cephalosporins and penicillins via the corresponding $\beta$-configuration at $\mathrm{C}_{(3)}$, but they have no therapeutic significance.<smiles>[R]C(=O)N[C@]1(OC)CN(S(=O)(=O)O)C1=O</smiles>

(1)<smiles>[R]C(=O)N[C@]1([R])C(=O)N(S(=O)(=O)O)C1([R])[R]</smiles>

(2)

The synthetic oxamazins (3) Woulfe et al., 1984, $1985^{4}$ and Breuer et al., 1985 $5^{5}$, thiamazins (4), Woulfe et al., $1986^{6}$, and monosulfactams (5) Miller et al., 1983', showed some antibacterial activity which raised again a major interest in the area of 2-azedinone chemistry. Other examples include monophosphams (6) and monocarbams (7) Durckheimer et al., $1985^{2}$.

The activated $\beta$-Lactam unit was a salient feature of these antibacterials, but also the nature and sterical arrangement of the substituents play a major role in the antibacterial activity and pharmacokinetics Durckheimer et al., $1985^{2}$.

The 3-isopropylidenyl- and 2-isopropyl N-acylazetidin-2-ones (8), (9) and further functionalized derivatives are novel synthetic monocyclic $\beta$-Lactams exhibiting in vitro antibacterial activity versus anaerodes and Gram-positive aerobes Brickner et al., $1987^{8}, \mathbf{1 9 9 2}^{9}, 1993^{10}$. A unique structural aspect differentiating them from other classes of $\beta$-Lactam antibiotics is the lack of any negatively charged group appended to the Lactam nitrogen. 
<smiles>[R1]C(=O)N[C@H]1C(=O)N(OCC(=O)O)C1([R1])[R1]</smiles>

(3)<smiles>[R10]OP(=O)([O-])N1CCN(C([R1])=O)C1=O</smiles><smiles>CC=C1CN(C(=O)O)C1=O</smiles>

(8)<smiles></smiles>

(4)<smiles>[R]C(=O)N[C@@H]1CN(C(=O)NS(=O)(=O)NC([R4])=O)C1=O</smiles>

(7)<smiles>CC(C)=C1CN(C(=O)c2ccccc2)C1=O</smiles>

(9)

Analogs of monobactams in which the sulfonic group has been replaced by the isosteric tetrazole, for example, (10), represent a new class of antibacterials Andrus et al., $1984^{11}$, Klich et al., $1984^{12}, 1993^{13}$, and Yoshida et al., $1986^{14}$.<smiles>CC(C)(C)OC(=O)N[C@H]1C(=O)N(c2nnn(Cc3ccccc3)n2)C1CF</smiles>

(10)

The so-called tabtoxinine- $\beta$-Lactam (11) is considered to be the active from of tabtoxin, a dipeptide exotoxin, produced by pseudomonas tabaci, the organism responsible for the wildfire disease of tobacco plants Baldwin et al., $1986^{15}$<smiles>N[C@@H](CC[C@]1(O)CNC1=O)C(=O)O</smiles>

(11)

Antielastase activity of 1,3,4-trisubstituted 2-azeti-dinones has been determined against enzymes, for example, human leucocyte elastase Shah et al., $1993^{16}$ and Adonias et al., $1993^{17}$.

\section{Biological activity of thiazoles:}

Paolo Vicini et al., 2006 ${ }^{18}$ were reported that, a totally synthetic molecule of the oxazolidinone class has been approved for human use and consistent with its activity aganist resistant Gram positive organism, appeared to have a unique mechanism of antibacterial activity. Also, They reported the synthesis of a new class of structurally novel 4-thiazolidinone derivatives incorporating two known bioactive heterocyclic nuclei such as thiazole and thiazolidinone Paolo Vicini et al., 2006 ${ }^{18}$.

Rosaria et al., $2005^{19}$ were reported that, thiosemicarbazone and 4-thiazolidinone derivatives were synthesized in one and two steps from thiosemicarbazide. The synthesize compounds were submitted to evaluation against host cells infected with Toxoplasma gondii. Their studies showed that thiosemicarbazones (16) and 4thiazolidinone derivatives (17) were effective against intracellular T. gondii. The biological activities of these thiosemicarbazones was related to their abilities to form complex with metal catios. The following scheme shows the synthetic route for the preparation of these compounds. Also, Thiosemicarbazone and 4-thiolidinone derivatives were synthesized in one and two step from thiosemicarbazide, in satisfactory yield. Then, the synthesized compounds were submitted to evaluation against host cells infected with Toxoplasma gondii. Recent studies using hydroxyurea (HU) demonstrate its efficacy, in eliminating the intracellular parasites of T. Gondii, Trypanosoma cruzi and Leishmania amazonensis (12), (13) and (14). Biological activities of these thiosemicarbazones are related to their abilities to form complex with metal cations Romulo P. Tenorio et al., $2005^{20}$. 
<smiles>NC(=O)NO</smiles>

(12)<smiles>NC(=S)NN=C[AlH2]</smiles>

(13)<smiles>[Y8]C=NN=C1SC(CC(=O)O)C(=O)N1P</smiles>

(14)<smiles>CCNC(=S)C(N)C=NC=CC(=O)O</smiles><smiles>[Y9]C=NN=C1CC(CC(=O)O)C(=O)N1[R]</smiles>

(17)

Jérôme et al., 2004 ${ }^{21}$ were reported that, The heterocycles of thiazolinone or its tautomeric form, display diverse biological activities such as tuberculostatic, anti-inflammatory, antidiabetic, antihydroidal, fungicidal, bactericidal and pesticidal, the 2,4-thiazolidinone (TZD) class is particularly important as therapeutic agents and has been thoroughly investigated as PPA- $\gamma$ agonists that led to the development of several insulin-sensitizing drugs such as Troglitazone (18), and Rosiglitazone (19) and compound (20) exhibit anti-inflammatoryJérôme et al., $2004^{21}$.<smiles>Cc1cc(N(C)CCOc2ccc(C[C@H]3SC(=O)NC3=O)cc2)c(O)c(C(C)(C)C)c1OCC(C)(C)c1cc(/C=C2/SC(=O)N(O)C2=O)cc(C(C)(C)C)c1O</smiles>

Masahiko Seki et al., $2003^{22}$ have been reported that, the proper selection of a protective group is one of the most significant criteria for developing an efficient synthetic method. The protective group in order to produce the number of steps leading to the target compound. In our investigation toward a practical synthesis of (+)biotin (21) development of a novel and efficient thiol protective group of cysteine (22) was needed Masahiko Seki et al., $2003^{22}$.<smiles>O=C(O)CCCC[C@H]1SC[C@@H]2NC(=O)N[C@@H]21</smiles>

(+)-Biotin (21)<smiles>N[C@@H](CS)C(=O)O</smiles>

L-Cysteine (22)

Thiazole derivatives such as pencillins (23) which have fused thiazolidine and $\beta$-Lactam rings were

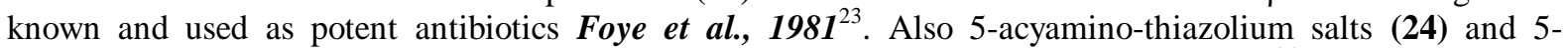
acylamothiazolidine had been reported to exhibit antibiotic activity Pirotte et al., 1991 ${ }^{24}$. A wide range of thiazole-containing metabolites had isolated and characterzed from marine organisms North et al., $\mathbf{1 9 9 0}^{25}$ and Pattenden et al., 1992 ${ }^{26}$. Among those compounds were patellamides, a class of thiazole-containing cyclic peptides which exhibit antineoplastic and activities Ireland et al., $\mathbf{1 9 8 0}^{27}, \mathbf{1 9 8 2}^{28}$, Wasylyk et al., $1983^{29}$ and McDonald et al., $\mathbf{1 9 9 2}^{30}$. Other thiazole-containing cyclic peptides of interest due to their antibiotic activity are keramamides Itagaki et al., 1992 ${ }^{31}$, Koerber et al., 1994 ${ }^{32}$ and thiotipin Yun et al., 1994 ${ }^{33}$. Cyclothiazomycin was a polythiazole containing peptide produced by streptomyces sp. which exhibited an important renin inhibitory activity Aoki et al., $1991^{34}$. 
<smiles>[R]OC(=O)NC1C(=O)N2C1SC(C)(C)C2C([R])=O</smiles>

(23)<smiles>[R]OC(=O)C[n+]1csc(NC(=O)[O-])c1</smiles>

(24)

Mycothiazole (25) was isolated from spongia mycofijiensis, a marine sponge. This compound shows anti-helmintic activity in vitro while high toxicity was observed in mice Crews et al., 1988 ${ }^{35}$. 6Hydroxybenzothiazole-2-sulfonamides $(\mathbf{2 6}, \mathrm{R}=\mathrm{H})$ were topically active carbonic anhydrase inhibitors Woltersdorf et al., $1989^{36}$. This activity confers to these compounds a potential utility as antiglaucoma drugs. Curacin A (27) is an anti-micotic which has been isolated from Lygbya majuscule a cyanobacteria Gerwick et al., $1994^{37}$ and whose absolute configuration has been elucidated Nagle et al., 1995 ${ }^{38}$. Formyl imidazo-[2,1b]thiazoles (28) have been proved to be effective as herbicides Andreani et al., 1991 ${ }^{39}$. Benzothiazolinones (29) show plant grow-stimulating effect Tralic-kulenovic et al., $1993^{40}$ and Sutoris et al., $1993^{41}$. Some thiazolidin2-thione derivatives showed hepatoprotective activities both in vitro and in vivo studies Yoneda et al., $1993^{42}$. Thiazolohalostatin (30) was produced by Actinomadura sp. It prevented cell death caused by calcium overload and exhibits an inhibitory activity against lipid peroxidation [Yamagishi et al., $1993^{43}$ ].

Certain 4-thiazolin derivatives (31) show significant activity as anti-convulsant agents Ergenc et al., 1994 ${ }^{44}$. thiazolo[3,4-a]benzimi- dazoles (32) show reproducible in vitro anti-HIV activity Cimirrie et al., 1991 $^{45}$.<smiles>C=CC/C=C/Cc1csc(C(C)(C)C(O)C/C=C\C(=C)CCNC(=O)OC2CCC3SC(=O)NC3C2)n1</smiles><smiles>C=CCC(C)CC/C(C)=C/C=C/CC/C=C/C1CSC([C@H]2CC2C)=N1</smiles>

(26)

(27)<smiles>[R]c1nc2sccn2c1C=O</smiles>

(28)<smiles>O=C(O)Cn1c(=O)sc2cccc([Tl])c21</smiles>

(30)<smiles>CCC(O)C1=C(Cl)C(Cl)=C(Cl)C1</smiles><smiles>CC(=O)C(C)CC(C)CC(C)C1=NC(C)(C(=O)O)CS1</smiles>

(29)<smiles>[Y]C1=C([Y])S(=NC(=[Ge])c2ccco2)CN1[Y]</smiles><smiles>[Al]C1CSCc2nc3ccccc3n21</smiles>

Schnur et al., $1991^{46}$ were reported that, Guanidino-thiazoles such as famotidine $\left(\mathbf{3 3}_{\mathrm{a}}\right)$ were known to be

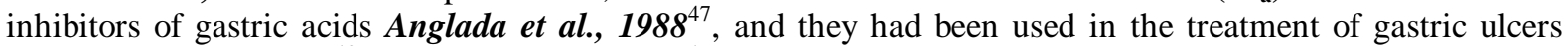
Montserrat et al., $1985^{48}$ an Richter et al., $1986^{49}$. This class of compound, i.e., $\omega$-aminoalkylthiazoles, was of interest because of their analogy with histamine Liebscher et al., 1994. $\left(\mathbf{3 3}_{\mathrm{b}}\right)$ were found to be systemically active against lung carcinomas Schnur et al., $1991^{46}$.<smiles></smiles><smiles>[R]c1ccc2sc(NC(=O)c3cs[n+](C(N)N)n3)nc2c1</smiles> 


\section{Biological activity of quinones and pyrazoles:}

Tung T. Dang et al., $2008^{51}$ have found that, Pyrazole-3-carboxylic acid derivatives represent important building blucks in organic and medicinal chemistry because their pharmacological properties. For example, pyrazole-3carboxylic acids and pyrazolo[1,5-c]quinazoline-2-caboxylates are nicotinic acid receptor agonists, bis(benzo[g] indazol-3-carboxamides) exhibit antiproli-ferative activity against various cancer cell lines. Ethyl5-propyl-1H-pyrazol-3-carboxylate is a key intermediate for the synthesis of Viagra Tung T. Dang et al., $2008^{51}$.

Asuncion Burguete et al., 2007 $7^{52}$ have been reported that, Quinoxalines, including their fused derivatives, display diverse pharmacological activities (antiviral, anticancer and antibacterial). The united kingdom have found that, quinoxaline is a potential treatment for HIV infection and works well with lamivudine, abacavir and efavirenz. Oxidation of both nitrogens of the quinoline ring dramatically increased the diversity of certain biological properties such as antibacterial activity and hypoxia-selective anticancer activity. Mogilaiah $\boldsymbol{e t}$ $a^{a}$. 1999 $^{53}$, were involved in the synthesis and biological evaluation of new agents derived from quinoxaline-1,4di-n-oxide Asuncion Burguete et al., 2007 ${ }^{52}$.

Claudia Valente et al., $2007^{54}$ were reported that, Quinones play vital roles in the biochemistry of living cells, where, they are involved in cellular respiration, phytosynthesis and cellular defence against bacteria, fungi and parasites. They became more important because their interesting their pharmacological actions, like as, antitumer, trypanocidal, anti-inflammatory, antiviral and antifungal. Some have reached clinical use as antineoplastic drugs Claudia Valente et al., $2007^{54}$.

Ashok Kumar et al., $2007^{55}$ have been reported that, Quinazoline nucleus an its derivatives have been found to possess wide spectrum of activities like antibacterial, antifungal, anticonvulant and anti-inflammatory. Compound (34) showed maximum antiinflammatory and analgesic activity Ashok Kumar et al., 2007 ${ }^{55}$.<smiles>O=C1CSC(c2ccccc2Cl)N1NCc1nc2ccc(Br)cc2c(=O)n1C1=CC2=CCC(c3ccc(Cl)cc3)=C21</smiles>

(34)

4-Thiazolidinone derivatives are known to possess antibacterial, antifungal, antiviral and antituberculosis propeties (35), (36), (37), (38). Peptidoglycan is an essential component of the cell wall of both Gram-positive and Gram-negative bacteria. 4-Thiazolidinones have been reported as novel inhibitors of the bacterial enzyme Mur B which is a precursor acting during the biosynthesis of peptidoglycan Guniz KucuKguzel et al., $2006^{56}$.

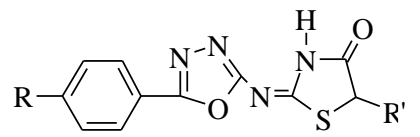

(35) antibacterial activity Ref. (1)

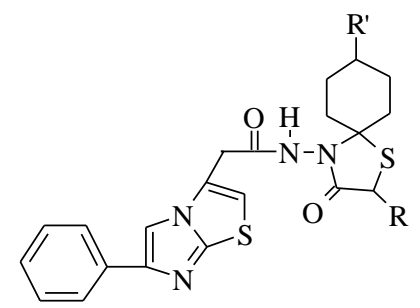

(37) antimycobacterial activity

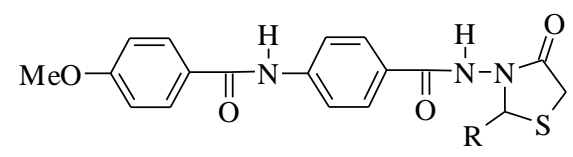

(36) antimycobacterial activity, Ref.(4)<smiles>[R][Y]1=C([R])C=C([R])[Y]([H])C1N1C(=O)CSC1c1c([R])ccc([R4])c1[R]</smiles>

(38) antiviral activity

Juan Ftncisco et al., 2004 ${ }^{57}$ were reported that, Many tetrahydroisoquinoline antitumor antibiotics, such as saframycins and ecteinascidin 743 (ET-743, Yondelis) are potent cytotoxic agents and the side chain at the isoquinoline C1-position, it is known the antitumer activity of ET-743 (39),(40),(41) Juan Ftncisco et al., $2004^{57}$. 


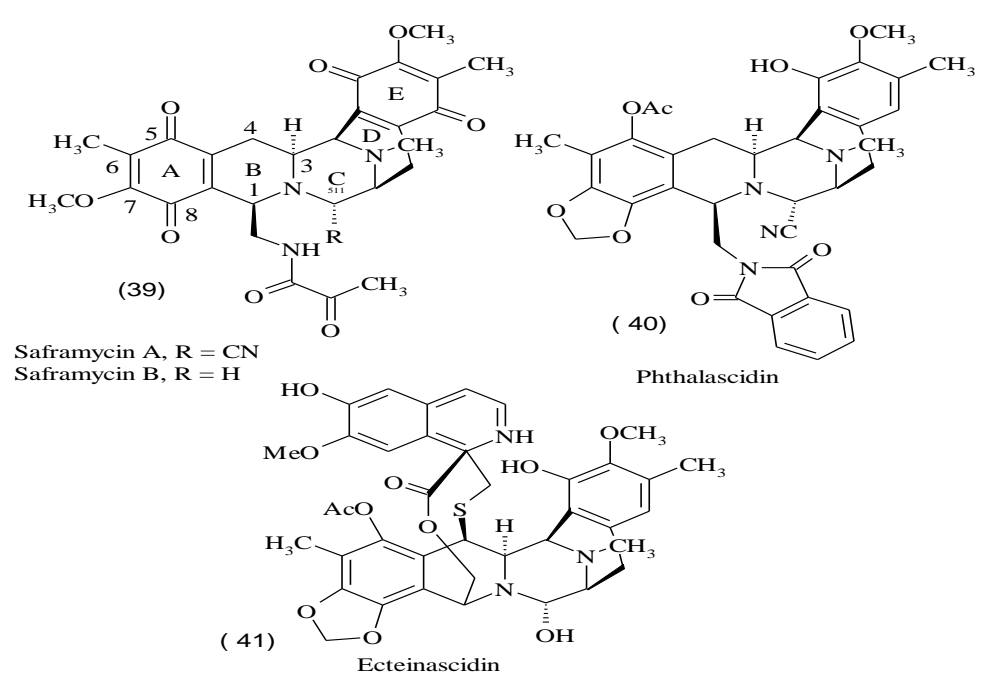

Peter Csomos et al., Tetrahedron, 64, 1002-1011, 2008

\section{References}

Durckheimer W., Blumbach J., Lattrell R. and Scheunemann K.H; Angew. Chem., 97, 183, 1985

Cimarusti C. and Sykes R.; Chem. Br., 19, 302, 1983.

Woulfe S.R. and Miller M.; J. Med. Chem., 28, 1447, 1985.

Breure H., Straub H., Treuner U., Drossard J.M., Hoehn H. and landler K.; J. Antibiot., 38, 813, 1985.

Woulfe S.R. and Miller M.; J. Org. Chem., 51, 3133, 1986.

Miller M.J., Biswas A. and Krook M.A.; Tetrahedron, 39, 2571, 1983.

Brickner S.J.; Eur. Pat. 232017 (1987) (Chem. Abstr., 1987, 107, 236366).

Brickner S.J., Gaikema J.J., Zurenko G.E., Greenfield L.J., Manninen P. and Ulanowicz; J. Antibiot., 3, $2241,1992$.

Brickner S.J., Gaikema J.J., Greenfield L.J., Zurenko G.E. and Manninen P.R.; Bioorg. Med. Chem. Lett., 3, $2241,1993$.

Andrus A., Partridge B., Heck J. and Christensen B.; Tetrahedron Lett., 25, 911, 1984.

Klich M. an Teutsch G.; Tetrahedron Lett., 25, 3849, 1984.

Klich M. an Teutsch G.; Bioorg. Med. Chem. Lett., 3, 2429, 1993.

Yoshida Y., Tanaka K., Hattori R., Fukuoka Y., Komatsu M., Kishimoto S., Saikawa I.; J. Antibiot., 39, $215,1986$.

Baldwin J.E., Otsuka and Wallace P.M.; Tetrahedron, 42, 3097, 1986.

Shah S., Finke P., Brause K., Chanler G., Ashe B., Weston H., Maycock A., Murnford R. and Doherty J.; Bioorg. Med. Chem. Lett., 3, 2295, 1

Adonias m., Anaya J., Camara J., Canet E., Gateauolesker A., Gero S. D., Grande M. M. and Hernando J.I. M.; Bioorg. Med. Chem. Lett., 3, 2547, 1993

Paolo V. A.; Geronikaki, K, Anastasia, M. Incertia, F. Zania; Bioorg. Med. Chem., 14, 3859-3864, 2006.

RosariaOttana, Rosanna Maccari, Maria Letizia Barreca, Giuseppe Bruno, Archimede Rotondo, Antonietta Rossi, Giuseppa Chiricosta, Rosanna Di Paola, Lidia Sautebin, Salvatore Cuzzocrea, Maria Gabriella Vigorita; Bioorg. Med. Chem., 13, 42434252, 2005.

Rômulo P., TENORIO, Quím. Nova [online]., vol.28, n.6, pp. 1030-1037, 2005

Jerome Blanchet, Jieping Zhu; Tetrahedron Letters, 45, 4449-4452, 2004.

Masahiko S. , Mayumi K., Masanori H., Shin-ichi Y. ; Toshiaki S. , Tetrahedron letters, 44, 8905- 8907,2003.

Foye W.O.; "Principles of Medicinal Chemistry". $2^{\text {nd }}$ edn., Lea an Febiger, Philadephia, 1981.

Pirotti B., Delarge J., Coyette J. and Frere J.M.; J. Antibiot., 44, 844, 1991.

North M. and Pattenden G.; Tetrahedron, 46, 8269, 1990.

Pattenden G.; J. Heterocycl. Chem., 29, 607, 1992.

Ireland C. and Scheuer P.J.; J. Am. Chem. Soc., 102, 5688, 1980.

Iraland C.M., Durso Jr. A.R., Newman R.A. and Hacher M.P.; J. Org. Chem., 47, 1807, 1982.

Wasylyk J.M., Biskupiak J.E., Costello C.E. and Ireland C.M.; J. Org. Chem., 48, 4445, 1983.

McDonald L.A> Foster M.P., Philips D.R., Ireland C.M., Lee A.Y. an Clardy J.; J. Org. Chem., 57, 4616, 1992.

Itagaki F., Shigemori H., Ishibashi M., Nakamura T., Sasaki T. and Kobayashi J.; J. Org. Chem., 57, 5540, 1992.

Koreber-ple K. and Massiot G.; Synlett, 759, 1994.

Yun B.S., Hidaka T., Furihata K. and Seto H.; Tetrahedron, 50, 11659, 1994.

Aoki M., Ohtsuka T., Itezono Y., Yokose K., Furihata K. and Seto H.; Tetrahedron Lett., 32, 217, $221,1991$.

Crews P., Kakou Y. and Quinoa E.; J. Am, Chem. Soc., 110, 4365, 1988.

Woltersdorf Jr. O.W., Schwam H., Bicking J.B., Brown S.L. Desolms S.J., Fishman D.R., Graham S.L., Gautheron P.D., Hoffman J.M., Larson R.D., Lee W.S., Michelson S.R., Robb C.M., Share N.N., Strohmaier K.M., Sugrue M.F. and Viader M.P.; J. Med. Chem., 32, 2486, 1989.

Gerwick W.H., Proteau P.J., Nagle D.G., Hamel E., Blkhin A. and Slate D.L.; J. Org. Chem., 59, 1243, 1994.

Nagle D.G., Gerjds R.S., Doo H.D., Gerwick W.H., Kim T.S., Nambu M. and White J.D.; Tetrahedron Lett., $36,1189,1995$.

Andreani A., Rambaldi M., Locatelli A. and Andreani F.; Collect. Czech. Chem. Commun., 56, $2436,1991$.

Tralic-Kulenovic V., Fiser-Jakic L. and Lazarevic Z.; Spectrosc. Lett., 26, 1771, 1993.

Sutoris V., Gaplovsky A., Sekerka V. and Ertlp.; Chem Papers, 47, 251, 156, 260, 1993.

Yoneda K., Ota A. and Kawashima Y.; Chem. Pharm. Bull., 41, 876, 1993

Yamagishi Y., Matsuoka M., Odagawa A., Kato S., Shino K. and Mochizuki J.; Antibiot., 46, $1633,1993$.

Ergenc N. and Capan G.; Farmaco, Ed. Sci., 49, 133, 1994.

Cimirri A., Grasso S., Monforte A.M., Monforte P. and Zappala M.; Farmaco, Ed. Sci., 46, 817, 925, 1991. 
[46] Schnur R.C., Gallashun R.J. Singleton D.H., Grissom M., Sloan D.E., Goodwin P., McNiff A., Fliri A.F.J., Mongano F.M., Olson T.H. and Pollack V.A.; J. Med. Chem., 34, 1975, 1991.

[47] Anglada L., Marquez M., Sacristan A. and Ortiz J.A.; Eur. J. Med. Chem., 23, 97, 1988.

[48] Montserrat, Span ES 562, 303 (Apr. 1985), (Chem. Abstr. 1987, 107, 397965).

[49] Richer G. and Vegyeszeti G.R.; Belg. BE., 905, 409, (31 Dec. 1986), (Chem. Abstr., 1987, 107, 39795 $)$.

[50] Liebscher J. and Patzel M.; Synlett, 471, 1994.

[51] Tung T.D.,Christinef F., Helmar G. , Peter L., Tetrahedron 64(2008)2207-2215, online

[52] Asuncion Buguete, Bioorganic and medicinal chemistry letters, 17, 6439-6443,2007.

[53] Mogilaiah K., Rao R., Babu, Reddy, Narender K.; Indian J. Chem., Section B: Org. Chem. Include Med. Chem., 38B(7), 818-822, 1999 (Eng), National Institute of Science Communication, CSIR.

[54] Claudia Valente, Rui Moreira, Rita C. Guedes, Jim Iley, Mohammed Jaffar And Kenneth T. Douglas; Bioorganic \& Medicinal Chemistry, 15, 5340-5350, 2007.

[55] Ashok kumar, Chatrasal Singh Rajput, Sudhir Kumar Bhati; Biorg. Med. Chem., 15, 3089-3096, 2007.

[56] Guniz Kucukguzel, Ayla Kocatepe, Erik De Clereq, Fikrettin Sahin and Medine Gulluce; European J. Med. Chem., 41, 353-359, 2006.

[57] Juan Francisco Gonzalez, Elena De La Cuesta and Carmen Avendano; Teytrahedron, 60,

6319-6326, 2004 